\title{
First record of the eucalypt gall-wasp Leptocybe invasa (Hymenoptera: Eulophidae) from Uruguay
}

\author{
Primer reporte de la avispa agalladora del eucalipto Leptocybe invasa \\ (Hymenoptera: Eulophidae) para Uruguay
}

\author{
Carolina Jorge $^{\text {a*, Gonzalo Martínez }}{ }^{\text {, }}$, Demian Gómez ${ }^{\text {b }}$, Martín Bollazzi ${ }^{\text {c }}$ \\ *Autor de Correspondencia: a Universidad de la República, CENUR Noreste sede Tacuarembó, Instituto Superior de Estudios Forestales, \\ Ruta 5, km 387, Tacuarembó, Uruguay, tel.: 46333485 int. 262, carolina.jorge@cut.edu.uy \\ ${ }^{\mathrm{b}}$ INIA Tacuarembó, Programa Nacional de Producción Forestal, Laboratorio de Entomología, Tacuarembó, Uruguay. \\ c Universidad de la República, Facultad de Agronomía, Departamento de Protección Vegetal, Unidad de Entomología, \\ Montevideo, Uruguay.
}

\begin{abstract}
SUMMARY
Leptocybe invasa is a recently introduced forest pest, responsible for significant economic loss in Eucalyptus spp. plantations worldwide. The objective of this work is to report its presence in Uruguay, providing data of its distribution and biology. A survey for galls was conducted from 2013 to 2015. The presence of galls was confirmed in 15 out of 35 surveyed points and four out of 157 traps. Eucalyptus benthamii was recorded as a new host. Three periods of emergence were observed. Life cycle was completed only in $E$. tereticornis, E. camaldulensis and E. grandis.
\end{abstract}

Key words: gall-insects, Eucalyptus, forestry pests.

\section{RESUMEN}

Leptocybe invasa es una plaga forestal de reciente introducción, responsable de importantes pérdidas económicas en plantaciones de Eucalyptus spp. a nivel mundial. El objetivo de este trabajo fue reportar su presencia para Uruguay, aportar datos de distribución y biología. Se observó la presencia de agallas de 2013 a 2015, confirmada en 15 de 35 puntos muestreados y en cuatro de 157 trampas. Eucalyptus benthamii se registra como nuevo hospedero. Fueron observados tres períodos de emergencia de adultos. El ciclo de vida fue completado solamente en E. tereticornis, E. camaldulensis y E. grandis.

Palabras clave: insectos agallícolas, Eucalyptus, plagas forestales.

\section{INTRODUCTION}

Commercial forestry with Eucalyptus species reaches $80 \%$ of the forested area in Uruguay, leading, in 2013, to more than 590 million dollars in export goods (DIEA 2014). Eucalyptus globulus Labill and E. grandis W. Hill ex Maiden are the most planted species, while red gum trees (E. tereticornis Sm. and E. camaldulensis Dehnh.) have been extensively used as shade and shelter forest in cattle breeding. Paine et al. (2011) suggest a correlation between the increase of global area planted with Eucalyptus spp. and the arrival of new insects and diseases. This phenomenon has also been observed in Uruguay, particularly during the last decade (Martínez 2010).

The last wave of world invasive forest pests has been characterized by small, cryptic insects, notably gall forming species (Paine et al. 2011). The Eucalyptus gallwasps Ophelimus maskelli Ashmead 1900, Selitrichodes globulus La Salle and Gates 2009 and Leptocybe invasa Fischer and La Salle 2004 are well known because of their economic importance, though the latter is particularly relevant due to the aggressiveness of the attack and its rapid dispersion (Paine et al. 2011).

The Australian gall wasp L. invasa was first recorded from South America in 2008; in Brazil in 2008, Argentina in 2010 and Chile in 2014 (Wylie and Speight 2012, SAG 2014). This insect has become a relevant pest for eucalypt forestry worldwide. Life cycle occurs almost entirely inside the gall. In temperate regions, the developmental cycle lasts 130 days on average leading to the occurrence of 2-3 generations annually (Mendel et al. 2004, Aquino et al. 2011), reaching to 5-6 generations in tropical areas (Zhu et al. 2012). Thelytokous parthenogenesis is the most common reproductive mechanism in L. invasa (Mendel et al. 2004). The objective of this work is to report the presence of $L$. invasa in Uruguay and the first mention of Eucalyptus benthamii as its host. 


\section{METHODS}

Occurrence of galls on eucalypt was recorded for the first time in April 2011 in Montevideo during an expert visit (3450'10.96” S; 56 $13^{\prime} 11.77^{\prime \prime}$ W). From August 2013 to August 2015 we conducted a survey of galls on eucalypt trees in plantations and shade and shelter forests. Thirtyfive sites were selected following two criteria: (1) presence of Eucalyptus species susceptible to L. invasa and (2) proximity to wood transport routes. All sites were inspected monthly to observe gall development. Adult wasps for identification were obtained from two sites located on E. tereticornis $\mathrm{x}$ E. camaldulensis hybrids and E. grandis at INIA Experimental Station (Tacuarembó). Additional points of occurrence were obtained from the review of 157 yellow sticky traps belonging to the National Monitoring System (Martínez et al. 2014).

The observation of specimens was made under a stereoscopic microscope Zeiss Stemi DV4 and by Scanning Electron Microscope (SEM) JEOL 5900 Low Vacuum. We followed Mendel et al. (2004) to determine the adult wasps and to describe gall morphology and we compared the individuals against identified material kept in the Forest Entomological Collection of INIA in Tacuarembó, Uruguay.

\section{RESULTS}

Gall and adult sampling. Gall occurrence was confirmed on 15 out of 35 surveyed points (figure 1). Emergency was confirmed on E. tereticornis $\mathrm{x}$ E. camaldulensis and E. grandis in three periods: August-September, mid-December and March-April. Only four out of 157 sticky traps checked contained adult wasp of $L$. invasa within the same three periods observed in the field survey (figure 1).

Material examined. Uruguay, Tacuarembó: INIA Experi-

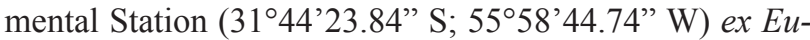
calyptus tereticornis $\mathrm{Sm}$. (three female adults).

Leptocybe invasa is a small wasp (1.1-1.4 mm) brownish in color with blue green metallic shine on the thorax (figure 2A). Specimens were ascribed to $L$. invasa based on the antennal morphology, thoracic morphology and wing venation (figure 2B-D). Detailed diagnosis of adult female was provided by Mendel et al. (2004). Scape longer than the pedicellum with broadened middle section. Flagellum with six segments separated by four annelli, the basal segments constitute the funiculum and the three apical segments form the antennal mass (figure 2B). Short prothorax; well-developed mesothorax; scutellum divided into three

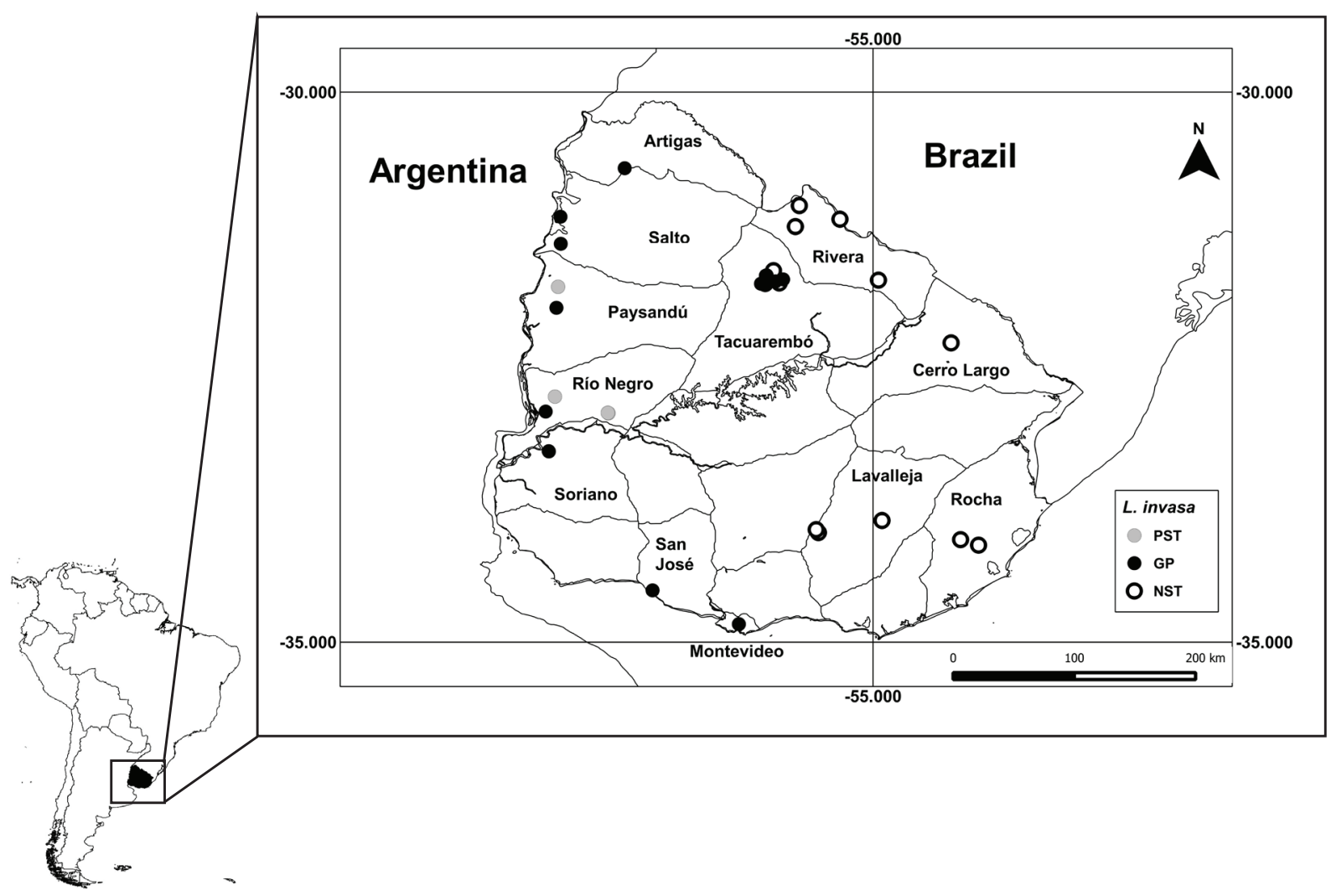

Figure 1. Occurrence of L. invasa in Uruguay. On yellow sticky cards: grey dots = presence; white dots = absence; black dots = presence of galls on survey points.

Presencia de L. invasa en Uruguay. En trampas amarillas: puntos grises = presencia; puntos blancos = ausencia; puntos negros $=$ presencia de agallas en puntos inspeccionados. 
separated zones by sublateral lines (figure 2C). Hyaline wings completely covered with setae, slight wing venation (figure 2D). Post marginal vein is shorter than stigmal vein. Submarginal vein presents 2-5 setae, visible on dorsal view. Identified material was deposited in the Forestry Entomological Collection of INIA in Tacuarembó, Uruguay.

Galls of $L$. invasa are always located in the central rib or in leaf petioles (figure 3A). Early attack is observed in the form of rectilinear wounds on the epidermis, which are inflicted by females during oviposition (figure 3B). Induced galls can cause deformation on leaves and apical shoots (figure 3C). Severe attacks can produce tissue necrosis and defoliation (figure 3D).

Table 1 reviews eucalypt species reported as susceptible to L. invasa. We observed for the first time the occurrence of galls on E. benthamii. Additionally, we observed

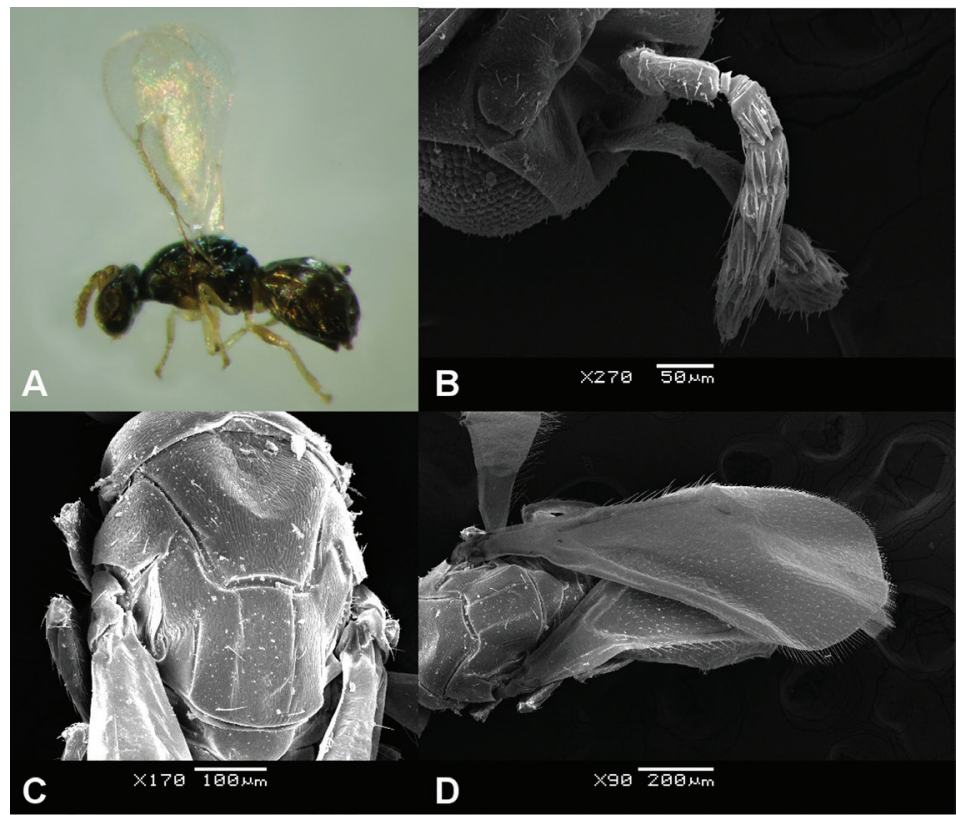

Figure 2. Adult female of Leptocybe invasa: A) Lateral view, body length $1.2 \mathrm{~mm}$. B) Antenna. C) Thorax. D) Wings. Hembra adulta de L. invasa: A) Vista lateral, longitud del cuerpo1,2 mm. B) Antena. C) Tórax. D) Alas.

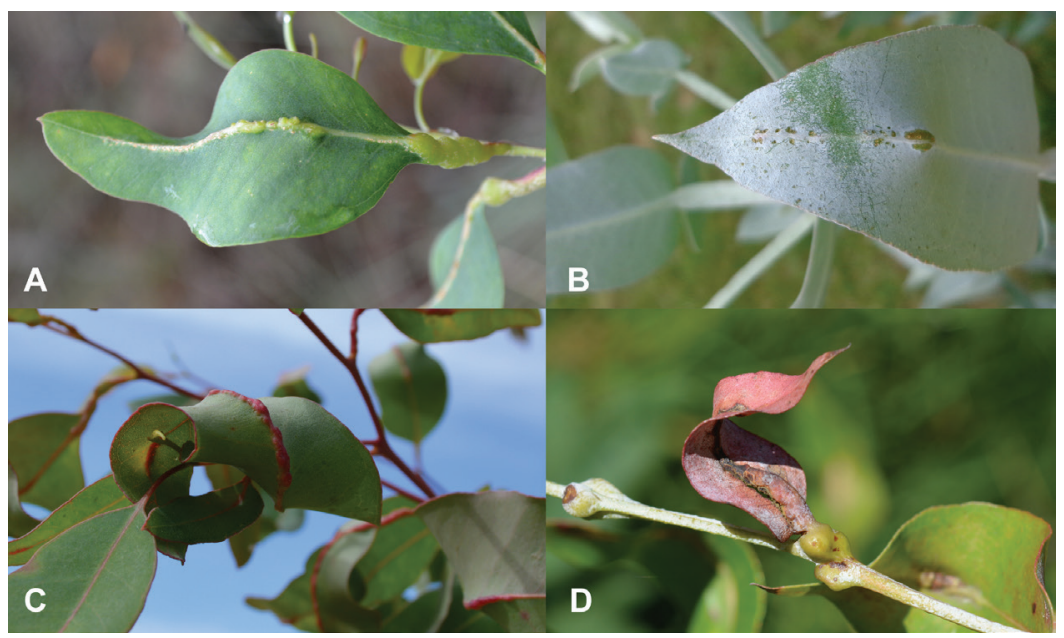

Figure 3. A) Shape and typical position of galls of Leptocybe invasa in Eucalyptus tereticornis x E. camaldulensis. B) Oviposition marks in E. globulus. C) Anomalous development on young plant in E. grandis. D) Necrosis and death of leaves and stems as a consequence of the attack by L. invasa in E. globulus.

A) Forma y posición típica de agallas de L. invasa en E. tereticornis x E. camaldulensis. B) Marcas de oviposición en E. globulus. C) Desarrollo anómalo en plantas jóvenes de E. grandis. D) Necrosis y muerte de hojas y ramas a consecuencia del ataque de L. invasa en E. globulus. 
Table 1. Reported hosts for Leptocybe invasa. N.S.: Not specified.

Hospederos reportados para Leptocybe invasa. N.S.: No especificado.

\begin{tabular}{|c|c|}
\hline Species & Countries/Sources \\
\hline \multicolumn{2}{|l|}{ Subgenus: Idiogenes } \\
\hline E. cloeziana F. Muell & N.S. (Nadel and Slippers 2011) \\
\hline \multicolumn{2}{|l|}{ Subgenus: Monocalyptus } \\
\hline E. pilularis $\mathrm{Sm}$. & Vietnam (Quang Thu et al. 2009), N.S. (Nadel and Slippers 2011) \\
\hline \multicolumn{2}{|l|}{ Subgenus: Nothocalyptus } \\
\hline E. microcorys Muell. & Vietnam (Quang Thu et al. 2009), N.S. (Nadel and Slippers 2011), China (Zhu et al. 2012) \\
\hline \multicolumn{2}{|l|}{ Subgenus: Symphyomyrtus } \\
\hline Eucalyptus alba Reinw. ex Blume & N.S (Nadel and Slippers 2011) \\
\hline E. botryoides Sm. & Israel (Mendel et al. 2004), N.S. (Nadel and Slippers 2011) \\
\hline E. bridgesiana Baker & Israel (Mendel et al. 2004), N.S. (Nadel and Slippers 2011), N.S. (FAO 2012) \\
\hline E. camaldulensis Dehnh. & $\begin{array}{l}\text { Israel (Mendel et al. 2004), Uganda (Nyeko et al. 2010), Vietnam (Quang Thu et al. 2009), } \\
\text { Argentina (Aquino et al. 2011, Nadel and Slippers 2011), N.S (FAO 2012), China (Zhu et al. } \\
\text { 2012, Luo et al. 2014), Brazil (Cegatta and Villegas 2013), Mozambique (Chirinzane et al. } \\
\text { 2014) Chile (SAG 2014) }\end{array}$ \\
\hline E. cinerea F. Muell. ex Benth. & N.S (FAO 2012) \\
\hline E cladocalyx Muell. & N.S (Nadel and Slippers 2011) \\
\hline E. coolabah Blakely et Jacobs & Vietnam (Quang Thu et al. 2009) \\
\hline E. dunnii Maiden & $\begin{array}{l}\text { Kenya (Nyeko et al. 2010), N.S. (Nadel and Slippers 2011), N.S. (FAO 2012), China (Zhu et } \\
\text { al. 2012) }\end{array}$ \\
\hline E. excerta Muell. & China (Zhu et al. 2012) \\
\hline E. globulus Labill. & $\begin{array}{l}\text { Israel (Mendel et al. 2004), Uganda (Nyeko et al. 2009), N.S (Nadel and Slippers 2011), N.S. } \\
\text { (FAO 2012) Chile (SAG 2014) }\end{array}$ \\
\hline E. gomphocephala D.C. & N.S. (Nadel and Slippers(2011) \\
\hline E. grandis Hill ex Maiden & $\begin{array}{l}\text { Israel (Mendel et al. 2004), Vietnam (Quang Thu et al. 2009), Kenya and Uganda (Nyeko et al. } \\
\text { 2010), N.S. (Nadel and Slippers 2011), N.S (FAO 2012) }\end{array}$ \\
\hline E. gunnii Hook. F. & Israel (Mendel et al. 2004) \\
\hline E. leucoxylon Muell. & N.S. (Nadel and Slippers 2011) \\
\hline E. maidenii Muell. & $\begin{array}{l}\text { Uganda (Nyeko et al. 2009), Vietnam (Quang Thu et al. 2009), N.S. (Nadel and Slippers 2011), } \\
\text { N.S. (FAO 2012) }\end{array}$ \\
\hline E. moluccana Roxb. & Vietnam (Quang Thu et al. 2009) \\
\hline E. nicholii Maiden et Blakely & N.S. (FAO 2012) \\
\hline E. nitens Deane et Maiden & N.S. (Nadel and Slippers 2011) \\
\hline E. pellita Muell. & Vietnam (Quang Thu et al. 2009), N.S. (Nadel and Slippers 2011) \\
\hline E. propinqua Deane et Maiden & China (Zhu et al. 2012) \\
\hline E. pulverulenta Sims & N.S. (FAO 2012) \\
\hline E. robusta $\mathrm{Sm}$. & $\begin{array}{l}\text { Israel (Mendel et al. 2004), Uganda (Nyeko et al. 2010), Vietnam (Quang Thu et al. 2009), } \\
\text { N.S. (Nadel and Slippers 2011), N.S. (FAO 2012), China (Zhu et al. 2012) }\end{array}$ \\
\hline E. rudis $\mathrm{Sm}$. & N.S. (FAO 2012) \\
\hline E. saligna $\mathrm{Sm}$. & $\begin{array}{l}\text { Israel (Mendel et al. 2004), Vietnam (Quang Thu et al. 2009), Kenya and Uganda (Nyeko et } \\
\text { al. 2010), N.S. (Nadel and Slippers 2011), China (Zhu et al. 2012), Mozambique (Chirinzane } \\
\text { et al. 2014) }\end{array}$ \\
\hline E. sideroxylon Cunn. & N.S (Nadel and Slippers (2011)) \\
\hline E. smithii Baker & Vietnam (Quang Thu et al. (2009)), N.S (Nadel and Slippers (2011)) \\
\hline E. tereticornis Sm. & $\begin{array}{l}\text { Israel (Mendel et al. (2004)), Vietnam (Quang Thu et al. (2009)), Kenya (Nyeko et al. (2010)), } \\
\text { N.S (Nadel and Slippers (2011)), China (Zhu et al. (2012), Luo et al. (2014)) }\end{array}$ \\
\hline E. urophylla Blake & $\begin{array}{l}\text { Vietnam (Quang Thu et al. (2009)), Kenya (Nyeko et al. (2010)), N.S (Nadel and Slippers } \\
\text { (2011)), N.S (FAO (2012)), China (Zhu et al. (2012)) }\end{array}$ \\
\hline E. viminalis Labill. & Israel (Mendel et al. (2004)), N.S (Nadel and Slippers (2011)) \\
\hline
\end{tabular}


galls on red gums (E. tereticornis, E. camaldulensis and hybrids of these two species), E. dunnii, E. grandis and E. globulus. We only observed emergency holes on red gums and E. grandis in different growing stages in the field, we did not inspect greenhouses or nurseries.

\section{DISCUSSION}

We observed galls on six species already reported as susceptible, with the addition of $E$. benthamii. Emergence period observed in our study suggests that the duration of the life cycle in Uruguay could be on average 120 days, similar to other temperate regions (Aquino et al. 2011). The presence of emergency holes solely on E. grandis and red gums suggests that not all species are equally suitable to complete the cycle. However, from the point of view of forestry, gall formation per se may hamper the development of the tree stands implying additional costs for tree production.

We assume that $L$. invasa colonized Uruguay from Argentina. Data suggest that, as first reports were closer to the Uruguayan border (provinces of Buenos Aires and Entre Rios) than to Brazil (Bahia and São Paulo States (Costa et al. 2008), and no reports have been made yet by foresters from the East region of Uruguay.

We collected additional individuals from a network of yellow sticky traps already established for monitoring other forestry pests. Although sticky traps have been used in other countries for collecting L. invasa (Kumari et al. 2010, Zhu et al. 2012), identification of the captured micro-hymenopteran insects has proven a difficult task due to the conservation status of the specimens.

The report of $L$. invasa in the country poses a threat to Uruguayan commercial forestry, hence research should focus on the development of management strategies for this pest. Chemical control has been tested in Brazil and India (Kumari et al. 2010, Cegatta and Villegas 2013), although more than $80 \%$ of the commercial stands are certified under ISO or FSC standards in Uruguay, turning this option unlikely, or at least restricted to nurseries. Alternatively, plant breeding seems to be a promising long term control tool for this pest (Kulkarni 2010, Dittrich-Schröder et al. 2012, Zhu et al. 2012). Since we observed variation in susceptibility to L.invasa among Eucalyptus species and hybrids, future studies should focus on screening resistance to attack from L. invasa in national genetic stock. Biological control programs are currently being implemented in Israel (Kim et al. 2008), South Africa (Kelly et al. 2012, Dittrich-Schröder et al. 2014), Chile (SAG 2014) and Brazil (de Sá et al. 2015). National studies may focus on the identification of the most reliable biocontrol candidates for our ecological context.

\section{ACKNOWLEDGMENTS}

The authors want to thank the forestry companies UPM-Forestal Oriental S.A. and Weyerhaeuser Produc- tos S.A. for the access to their plantations. GMC wants to thanks Sociedad de Productores Forestales of Uruguay (SPF) for granting the access to the yellow sticky cards of the National Monitoring Scheme.

\section{REFERENCES}

Aquino AD, EN Botto, MS Loiacono, P Pathauer. 2011. Avispa de la agalla del eucalipto, Leptocybe invasa Fisher and La Salle (Hymenoptera: Eulophidae: Tetrastichinae), en Argentina. Revista INTA 37:159-164.

Cegatta IR, C Villegas. 2013. Eficiência de dois inseticidas sistêmicos no controle de Leptocybe invasa em mudas de Eucalyptus camaldulensis. Revista do Instituto Florestal 25:215-221.

Chirinzane CJ, MD de Souza, NJ Souza, EH Rezende, T Alves, RR Bandeira, AM Fernandes. 2014. First report of Leptocybe invasa Fisher and La'Salle (sic) (Hymenoptera: Eulophidae) in Mozambique. African Journal of Agricultural Research 9(49):3555-3558. DOI: 10.5897/AJAR2013.8109.

Costa VA, E Berti Filho, CF Wilcken, JL Stape, J La Salle and LD Teixeira. 2008. Eucalyptus gall wasp, Leptocybe invasa Fisher et La Salle (Hymenoptera: Eulophidae) in Brazil: new forest pest reaches the New World. Revista de Agricultura 83(2):136-139.

DIEA (Dirección de Estadísticas Agropecuaria, UY). 2014. Anuario Estadístico 2014. DIEA - MGAP. Accessed Jul. $1^{\text {st }}$, 2015. Available at: http://www.mgap.gub.uy/portal/page. aspx?2,diea,diea-anuario-2014,O,es,0,\%20.

Dittrich-Schröder G, M Harney, S Neser, T Joffe, S Bush, BP Hurley, MJ Wingfield, B Slippers. 2014. Biology and host preference of Selitrichodes neseri: A potential biological control agent of the Eucalyptus gall wasp, Leptocybe invasa. Biological Control 78:33-41. DOI: 10.1016/j.biocontrol.2014.07.004

Dittrich-Schröder G, MJ Wingfield, BP Hurley, B Slippers. 2012. Diversity in Eucalyptus susceptibility to the gall-forming wasp Leptocybe invasa. Agricultural and Forest Entomology 14(4):419-427. DOI: 10.1111/j.1461-9563.2012.00583.x

FAO (Food and Agriculture Organisation of the United Nation, IT). 2012. Leptocybe invasa Fisher and La Salle. FAO - Forestry Department. Accessed Jul. 20 $0^{\text {th }}, 2015$. Available at: http://www.fao.org/forestry/13569-05912e0e2fe9054c3ed4904ae597e3310.pdf.

Kelly J, J La Salle, M Harney, G Dittrich-Schröder, BP Hurley. 2012. Selitrichodes neseri n. sp, a new parasitoid of the eucalyptus gall wasp Leptocybe invasa Fisher and La Salle (Hymenoptera: Eulophidae: Tetrastichinae). Zootaxa 3333:50-57.

Kim IK, Z Mendel, A Protasov, D Blumberg, J La Salle. 2008. Taxonomy, biology, and efficacy of two Australian parasitoids of the eucalyptus gall wasp, Leptocybe invasa Fisher and La Salle (Hymenoptera: Eulophidae: Tetrastichinae). Zootaxa 1910:1-20.

Kulkarni HD. 2010. Screening eucalyptus clones against Leptocybe invasa Fisher and La Salle (Hymenoptera: Eulophidae). Karnataka Journal of Agricultural Sciences 23(1):87-90.

Kumari NK, HD Kulkarni, KB Goud. 2010. Biology of eucalyptus gall wasp, Leptocybe invasa Fisher and La Salle (Hymenoptera: Eulophidae). Karnataka Journal of Agricultural 
Sciences 23(1):211-212.

Luo J, R Arnold, W Lu, Y Lin. 2014. Genetic variation in Eucalyptus camaldulensis and E. tereticornis for early growth and susceptibility to the gall wasp Leptocybe invasa in China. Euphytica 196:397-411. DOI: 10.1007/s10681-013-1042-8.

Martínez G. 2010. Insectos plaga en plantaciones jóvenes de eucalipto: hacia un modelo. INIA. Serie Actividades de Difusión 629:9-24.

Martínez G, D Gómez, GS Taylor. 2014. First record of the Australian psyllid Blastopsylla occidentalis Taylor (Hemiptera, Psylloidea) from Uruguay. Transactions of the Royal Society of South Australia 138(2):231-236.

Mendel Z, A Protasov, N Fisher, J La Salle. 2004. Taxonomy and biology of Leptocybe invasa gen. et sp. n. (Hymenoptera: Eulophidae), an invasive gall inducer on Eucalyptus. Australian Journal of Entomology 43:101-113.

Nadel RL, B Slippers. 2011. Leptocybe invasa, the blue gum chalcid wasp. ICFR, South Africa. Accessed Dec. 20 $0^{\text {th }}$, 2014. Available at: http://www.forestry.co.za/uploads/File/ home/notices/2011/ ICFR\%20IS01-2011gallwasp.pdf.

Nyeko P, KE Mutitu, BO Otieno, GN Ngae, RK Day. 2010. Variations in Leptocybe invasa (Hymenoptera: Eulophidae) population intensity and infestation on eucalyptus germplasms in Uganda and Kenya. International Journal of Pest Management 56(2): 137-144

Nyeko P, EK Mutitu, RK Day. 2009. Eucalyptus infestation by Leptocybe invasa in Uganda. African Journal of Ecology 47(3):299-307.
Paine TD, MJ Steinbauer, SA Lawson. 2011. Native and Exotic Pests of Eucalyptus: A Worldwide Perspective. Annual Review of Entomology 56:181-201. DOI: 10.1146/annurevento-120709-144817.

Quang Thu P, B Dell, TI Burgess. 2009. Susceptibility of 18 eucalypt species to the gall wasp Leptocybe inva$s a$ in the nursery and young plantations in Vietnam. ScienceAsia 35(2):113-117. DOI: 10.2306/scienceasia1513-1874.2009.35.113.

Sá LAN de, AR de Souza, LR Junqueira, MC Candelária, VA Costa, LR Barbosa, JC Zanuncio, CF Wilcken. 2015. Introdução do parasitoide Selitrichodes neseri (Hymenoptera: Eulophidae) para o controle da vespa-da-galha do eucalipto Leptocybe invasa (Hymenoptera: Eulophidae). Resumos do14 Simpósio de controle biológico. Teresópolis, Brasil.

SAG (Servicio Agrícola y Ganadero, CL). 2014. Leptocybe inva$s a$ Fischer et Lasalle (Hymenoptera: Eulophidae) Microavispa formadora de agallas en eucalipto. Servicio Agrícola y Ganadero. Accesed Jul. 22 ${ }^{\text {nd }}, 2015$. Available at: http:// www.sag.cl/ambitos-de-accion/leptocybe-invasa-fischer-lasalle-hymenoptera-eulophidae-microavispa-formadora-de

Wylie FR, MR Speight. 2012. Insect pests in tropical forestry. 2nd Edition. Oxfordshire, United Kingdom. CABI. 365 p.

Zhu F, S Ren, B Qiu, Z Huang, Z Peng. 2012. The Abundance and Population Dynamics of Leptocybe invasa (Hymenoptera: Eulophidae) Galls on Eucalyptus spp. in China. Journal of Integrative Agriculture 11(12):2116-2123. DOI: 10.1016/S2095-3119(12)60470-5. 